\title{
Extraction and physicochemical characterization of Sargassum vulgare alginate from Brazil
}

\author{
Marcia R. Torres, ${ }^{\text {a }}$ Alessandra P. A. Sousa, ${ }^{\text {a }}$ Eduardo A. T. Silva Filho, ${ }^{a}$ Dirce F. Melo, ${ }^{a}$ \\ Judith P. A. Feitosa, ${ }^{b}$ Regina C. M. de Paula ${ }^{\mathrm{b}, *}$ and Maria G. S. Lima ${ }^{\mathrm{a}}$ \\ ${ }^{a}$ Departamento de Bioquímica e Biologia Molecular, Universidade Federal do Ceará, CP 6020, CEP 60455-760, \\ Fortaleza, Ceará, Brazil \\ bepartamento de Química Orgânica e Inorgânica, Universidade Federal do Ceará, CP 12.200, CEP 60455-760, \\ Fortaleza, Ceará, Brazil
}

Received 24 November 2006; received in revised form 21 May 2007; accepted 22 May 2007

Available online 2 June 2007

\begin{abstract}
Alginate fractions from Sargassum vulgare brown seaweed were characterized by ${ }^{1} \mathrm{H}$ NMR and fluorescence spectroscopy and by rheological measurements. The alginate extraction conditions were investigated. In order to carry out the structural and physicochemical characterization, samples extracted for 1 and $5 \mathrm{~h}$ at $60{ }^{\circ} \mathrm{C}$ were further purified by re-precipitation with ethanol and denoted as SVLV ( $S$. vulgare low viscosity) and SVHV ( $S$. vulgare high viscosity), respectively. The M/G ratio values for SVLV and SVHV were 1.56 and 1.27, respectively, higher than the ratio for most Sargassum spp. alginates (0.19-0.82). The homopolymeric blocks $\mathrm{F}_{\mathrm{GG}}$ and $\mathrm{F}_{\mathrm{MM}}$ of these fractions characterized by ${ }^{1} \mathrm{H}$ NMR spectroscopy were 0.43 and 0.55 for $\mathrm{SVHV}$ and 0.36 and 0.58 for SVLV samples, respectively, these values typically being within $0.28-0.77$ and $0.07-0.41$, respectively. Therefore, the alginate samples from $S$. vulgare are much richer in mannuronic block structures than those from other Sargassum species. Values of $M_{\mathrm{w}}$ for alginate samples were also calculated using intrinsic viscosity data. The $M_{\mathrm{w}}$ value for SVLV $\left(1.94 \times 10^{5} \mathrm{~g} / \mathrm{mol}\right) \mathrm{was}$ lower than that for SVHV $\left(3.3 \times 10^{5} \mathrm{~g} / \mathrm{mol}\right)$. Newtonian behavior was observed for a solution concentration as high as $0.7 \%$ for SVLV, while for SVHV the solutions behaved as a Newtonian fluid up to $0.5 \%$. The optimal conditions for obtaining the alginates from $S$. vulgare were $60{ }^{\circ} \mathrm{C}$ and $5 \mathrm{~h}$ extraction. Under these conditions, a more viscous alginate in higher yield was extracted from the seaweed biomass.
\end{abstract}

(C) 2007 Elsevier Ltd. All rights reserved.

Keywords: Sargassum vulgare; Alginate; Brown algae; Viscosity; NMR spectroscopy

\section{Introduction}

Alginates are polysaccharides found in brown seaweeds and are composed mainly of linear polymers of $\beta$ - $(1 \rightarrow 4)$-D-mannuronic $(\mathrm{M})$ and $\alpha$-L-guluronic $(\mathrm{G})$ acids differing in terms of their proportions and linear arrangements. ${ }^{1}$ The sequence of monomers (M, G) changes greatly depending on the source (algal species or tissue). ${ }^{2}$ Although the main source of alginates is brown seaweed, similar polysaccharides are found in the capsulae of some soil bacteria. ${ }^{3}$ In brown seaweeds,

\footnotetext{
* Corresponding author. Tel.: +55 85 33669973; fax: +55 85 33669978; e-mail: rpaula@dqoi.ufc.br
}

alginates are the most abundant polysaccharides reaching up to $40 \%$ of the dry weight. ${ }^{4}$ They are mainly found in the cellular wall matrix. ${ }^{5}$ Matrix polysaccharides are produced by geobacteria Azotobacter vinelandii, Azotobacter crococum and some species of Pseudomonas. ${ }^{4}$

Alginates do not have any nutritional value; however, they are often employed as additives to change and stabilize the texture of foods. The most important alginate properties are the ability to form a gel and the stabilization of aqueous mixtures and emulsions. ${ }^{4}$

${ }^{1} \mathrm{H}$ NMR spectroscopy is the main technique used in the investigation of alginate composition and structural patterns. ${ }^{6-9}$ Alginate structures are generally constituted of homopolymeric blocks ( $\mathrm{M}$ blocks and $\mathrm{G}$ blocks) that 
can be separated by heteropolymeric blocks (MG blocks). ${ }^{9}$ The $\mathrm{M} / \mathrm{G}$ ratio and block structure have a strong effect on the physical properties of alginate.

The alginate and the biomass of Sargassum spp. have been reported to be suitable substrates for heavy-metal adsorption, and the adsorption parameters for $\mathrm{Cd},{ }^{10-12}$ $\mathrm{Au},{ }^{13} \mathrm{Cu},{ }^{7,14} \mathrm{Fe},{ }^{15} \mathrm{Ni},{ }^{16} \mathrm{~Pb},{ }^{17}$ and $\mathrm{Zn}^{7}$ have been investigated. Davis et al. ${ }^{10,11}$ showed that the amount of guluronic acid and of uronic acid diads and triads are the critical parameters in the use of alginate from Sargassum spp. for metal biosorption strategies. Also, in this regard, Donati et al. ${ }^{17}$ investigated the role of the $\mathrm{MG}$ sequence in the calcium alginate network.

Pharmacological experiments have revealed that polysaccharides extracted from Sargassum fusiforme markedly decrease the content of total cholesterol, triglycerides, and low-density hypoprotein cholesterol in rats. ${ }^{18}$ A crude extract of Sargassum polycystum has been shown to have a considerable effect in the prevention of severe lipid disturbances and to metabolize enzymes triggered by acetaminophen during hepatic injury. ${ }^{19}$

Alginate is employed as a matrix for encapsulation and/or release of cells ${ }^{20}$ and also for the release of drugs. ${ }^{21,22}$ It is also used in the form of microparticles for antigen release systems since it is unspecific, nontoxic and, most importantly, because it is approved by the US Food and Drug Administration. ${ }^{23}$ Oral administration of alginate microspheres induces systemic and mucosal immune response in a wide variety of animals. These microspheres act not only as a release system, but also as adjuvants since the induction of cytokines has been observed. ${ }^{23}$

Some reports on the seaweed Sargassum vulgare, mainly from Brazil, are available in the literature. An evaluation of the methods for extraction and quantification of protein from marine macro- and microalgae, including $S$. vulgare, is available in the literature ${ }^{24}$ as well as its amino acid composition. ${ }^{25}$ The chemical composition (protein, carbohydrate, lipids, fiber, ash, and nitrogen) of this seaweed was investigated in order to evaluate its potential nutritive value. ${ }^{26}$ An extract of S. vulgare algae at $5 \%$ concentration has shown $78.8 \%$ syncytium inhibitory activity toward the human T-cell lymphotropic virus (HTLV-1), and it may be useful in preventing infection. ${ }^{27}$ Another potential application of this seaweed is as biosorbent for heavy metals $(\mathrm{Cd}$ and $\mathrm{Cu}$ ). S. vulgare biomass uptakes more $\mathrm{Cd}$ and $\mathrm{Cu}$ than other Sargassum species (Sargassum filipendula and Sargassum fluitans). ${ }^{14}$ With regard to $S$. vulgare polysaccharides, the only relevant study found in the literature was published in 1995, which presented an overview of four main polysaccharides, ${ }^{28}$ with no alginate characterization.

Taking into account the potential application of $S$. vulgare alginate, its extraction conditions were investi- gated, and the alginates obtained were characterized. We intend to use these alginates in future studies as a matrix for enzyme and drug encapsulation.

\section{Materials and methods}

\subsection{Extraction and purification of alginates}

Specimens of the brown seaweed $S$. vulgare were collected in August 2001 from the Atlantic coast in northern Brazil (Pacheco Beach, Caucaia, Ceará). The samples were cleaned, washed in distilled water and stored at $-20{ }^{\circ} \mathrm{C}$. Alginates were extracted according to Calumpong et al. ${ }^{29}$ (modified procedure). The algae samples were dried to constant weight at $60^{\circ} \mathrm{C}$, then soaked in $2 \%$ formaldehyde for $24 \mathrm{~h}$, washed with water and then added to $0.2 \mathrm{M} \mathrm{HCl}$ and left for another $24 \mathrm{~h}$. After this time the samples were washed again in distilled water before extraction with $2 \%$ sodium carbonate. The extract was then divided into three aliquots.

Alginate extraction was monitored over time at different temperatures $\left(25,60\right.$, and $\left.80^{\circ} \mathrm{C}\right)$. Aliquots collected after different time periods were centrifuged, and the supernatants were labeled as crude extracts. The alginate sample was then obtained from the crude extract by precipitation with ethanol. The precipitate was washed twice with acetone and dried under ambient atmosphere.

The alginate fractions obtained by extraction at $60^{\circ} \mathrm{C}$ for $1 \mathrm{~h}$ and $5 \mathrm{~h}$ were purified by re-precipitation with ethanol as previously described and denoted as $S$. vulgare low-viscosity (SVLV) and $S$. vulgare high-viscosity (SVHV) samples, respectively.

\subsection{Fluorescence spectroscopy analysis}

Fluorescence spectra were obtained with a HITACHI F-2000 spectrofluorimeter following the procedure used by Klock et al. ${ }^{30}$ The alginate fractions (SVLV and SVHV) were dissolved in distilled water $(1 \% \mathrm{w} / \mathrm{v})$ and filtered through disposable membrane syringe filters $(0.2 \mu \mathrm{m})$. The excitation wavelength was $366 \mathrm{~nm}$, and the emission signals were observed in the range of $380-600 \mathrm{~nm}$.

\subsection{General characterization}

The protein content was calculated from the $\% \mathrm{~N}$ determined by elemental analysis using a multiplication factor of $6.25 .{ }^{26}$ Elemental microanalyses were performed in a Carlo Erba EA model 1108 equipment. The moisture content was obtained by heating $0.1 \mathrm{~g}$ of the samples at $105^{\circ} \mathrm{C}$ until constant weight. Samples of $0.1 \mathrm{~g}$ were heated at $600{ }^{\circ} \mathrm{C}$ until constant weight for ash determination. 


\subsection{Nuclear magnetic resonance spectroscopy}

${ }^{1} \mathrm{H}$ NMR spectra of $0.1 \%$ w/v solutions in $\mathrm{D}_{2} \mathrm{O}$ were recorded on a Fourier-transform Bruker Avance DRX 500 spectrometer, equipped with an inverse multinuclear gradient probe-head with $z$-shielded gradient coils, and with a Silicon Graphics Workstation, at 353 K. Chemical shifts are given in ppm relative to internal sodium 2,2dimethylsilapentane-5-sulphonate (DSS) at $0.00 \mathrm{ppm}$. Baseline correction was carried out prior to integration, and the block patterns were obtained through the average of three determinations of each sample. Samples were prepared for NMR analysis by the partial acid hydrolysis method. ${ }^{10}$

\subsection{Intrinsic viscosity}

The intrinsic viscosities were measured on an Ubbelohde viscometer, with $0.5-\mathrm{mm}$ capillary diameter, and with a solvent flow time $(0.1 \mathrm{M} \mathrm{NaCl})$ of $127.3 \mathrm{~s}$ at $25^{\circ} \mathrm{C}$. The initial alginate solutions (SVLV and SVHV) in a concentration of $30 \mathrm{mg} / 10 \mathrm{~mL}$ were prepared by stirring for at least $4 \mathrm{~h}$ at room temperature $\left(25^{\circ} \mathrm{C}\right)$. All flow times were mean values of at least five replicates.

\subsection{Rheological determinations}

The flow curves for SVLV and SVHV in $0.1 \mathrm{M} \mathrm{NaCl}$ aqueous solutions were obtained with a Brookfield rheometer, cone-plate model LV-DV-III, at $25^{\circ} \mathrm{C}$, over a range of polysaccharide concentrations from 0.1 to $1.0 \mathrm{~g} / \mathrm{dL}$.

\section{Results and discussion}

\subsection{Effect of extraction conditions on the yield and specific viscosity}

The alginate extraction was monitored over time at different temperatures. The alginate yield increased with temperature (Fig. 1a). After $3 \mathrm{~h}$ of heating the yields obtained at 60 and $80^{\circ} \mathrm{C}$ were similar. The best yield value was registered after $5 \mathrm{~h}$ of extraction at 60 or $80^{\circ} \mathrm{C}$. This value $(16.9 \%)$ is $40 \%$ higher than the yield for the sample extraction at $25^{\circ} \mathrm{C}$. Davis et al. ${ }^{10}$ found values in the range of $21.1-24.5 \%$ for $S$. fluitans and $16.3-20.5 \%$ for Sargassum oligocystum with variations being dependent on the alginate extraction method used. In another study, Davis et al. ${ }^{11}$ obtained higher yields for the same species, of $45 \%$ and $37 \%$, respectively. Also, yield values for Sargassum dentifolium, Sargassum asperifolium, and Sargassum latifolium of $3.25 \%, 12.4 \%$, and $17.7 \%$, respectively, have been reported. ${ }^{9}$ The average result obtained for $S$. vulgare is within the range reported for alginate from the Sargassum genus; however, it is lower
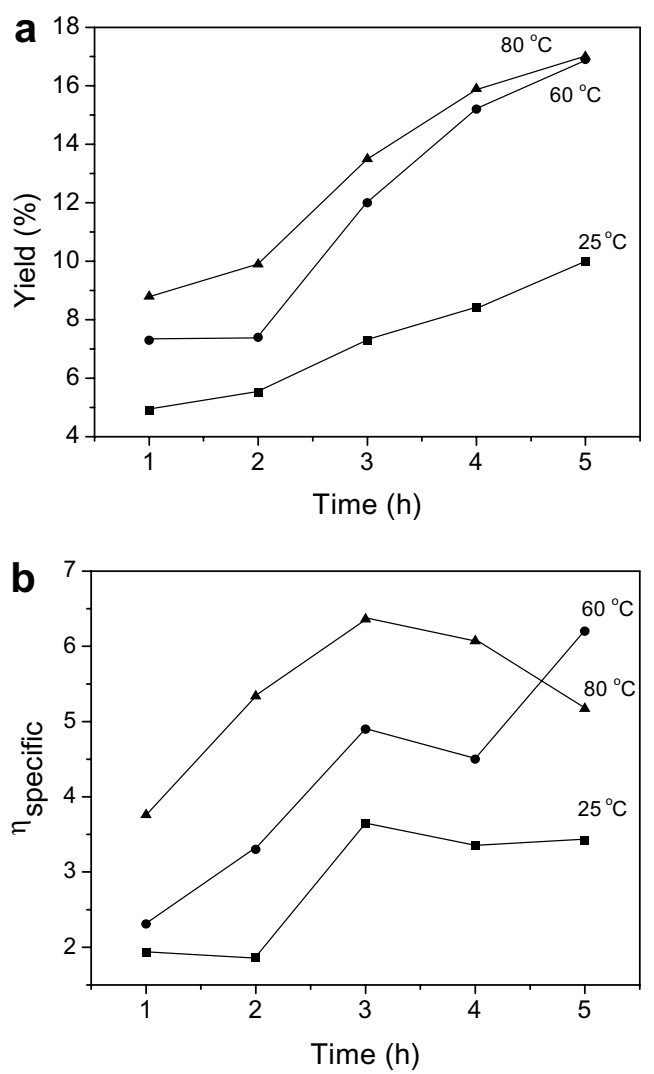

Figure 1. Effect of extraction conditions on yield (a) and specific viscosity (b).

than alginate from other algal species $(22-61 \%) .{ }^{8}$ The polysaccharide content of $S$. vulgare was less than that determined by Marinho-Soriano et al., ${ }^{26}$ possibly due to weight difference using protein, lipid, fiber, moisture, and ash content ( $67.8 \%$ of dry matter). The Sargassum seaweed polysaccharide is a unique mixture, mainly alginate and fucoidan. ${ }^{14}$ Taking into account that alginate is not the major component of $S$. vulgare polysaccharides, ${ }^{28}$ the yield value of $16.9 \%$ for alginate is not unexpected.

The effect of extraction time and temperature on specific viscosity can be seen in Figure 1b. An increase in the temperature of the extraction procedure resulted in higher solution viscosity, probably due to dissolution of high molar mass macromolecules. Since the extraction for $5 \mathrm{~h}$ at $60^{\circ} \mathrm{C}$ produced an alginate solution viscosity slightly higher than that at $80^{\circ} \mathrm{C}$, the optimal temperature for obtaining alginates from $S$. vulgare was established as $60^{\circ} \mathrm{C}$.

The analytical data obtained for SVLV and SVHV were similar (Table 1). The protein values determined through nitrogen content $(\% \mathrm{~N} \times 6.25)^{26}$ were 1.1 and 1.0 for SVHV and SVLV, respectively. Slightly different values for nitrogen content have been reported in the literature. ${ }^{26}$ The protein content of $S$. vulgare polysaccharides is very low when compared with that reported for 
Table 1. Analytical data of Sargassum vulgare alginates

\begin{tabular}{lcc}
\hline Analytical parameter $(\mathrm{m} / \mathrm{m} \%)$ & SVLV & SVHV \\
\hline $\mathrm{H}$ & 5.15 & 4.49 \\
$\mathrm{C}$ & 27.7 & 28.1 \\
$\mathrm{~N}$ & 0.178 & 0.164 \\
$\mathrm{~S}$ & 0 & 0 \\
Protein from N\% & 1.1 & 1.0 \\
Moisture & 14 & 16 \\
Ash & 2 & 1 \\
\hline
\end{tabular}

the total biomass (15.8\%). ${ }^{26}$ In a previous study, $S$. fluitans and Sargassum siliquosum alginate were found to contain no detectable nitrogen content; however, Sargassum thumbergii had $6.9 \%$ of protein. ${ }^{11}$

Considering the sodium alginate structure and the sample moisture content, the calculated $\mathrm{C}$ and $\mathrm{H}$ mass percentages were $32.1 \%$ and $4.13 \%$, respectively, for SVLV and $31.5 \%$ and $4.08 \%$, respectively, for SVHV. The experimental results were quite different, the $\% \mathrm{C}$ being lower and the $\% \mathrm{H}$ higher. This difference is greater for SVLV, being about $-4 \%$ for $\mathrm{C}$ and $+1 \%$ for $\mathrm{H}$. This could be because the moisture content at the moment of microanalysis was higher than the value given in Table 1 , and also, cations other than sodium may have been present.

\subsection{Fluorescence spectroscopy}

The alginate purity degree is very important for medical applications. Unpurified alginate can lead to the development of fibrotic cell overgrowth around the alginate microcapsules. The main contaminants are polyphenols, endotoxins, and proteins. ${ }^{31}$ The degree of purification of the alginates was verified by fluorescence spectroscopy, which can detect polyphenolic impurities often found in alginates. ${ }^{32}$ It can be noted in Figure 2 that the unpurified $S$. vulgare alginates showed the presence of residues emitting at $450 \mathrm{~nm}$. After dissolution and re-precipitation with ethanol, the fluorescence intensity

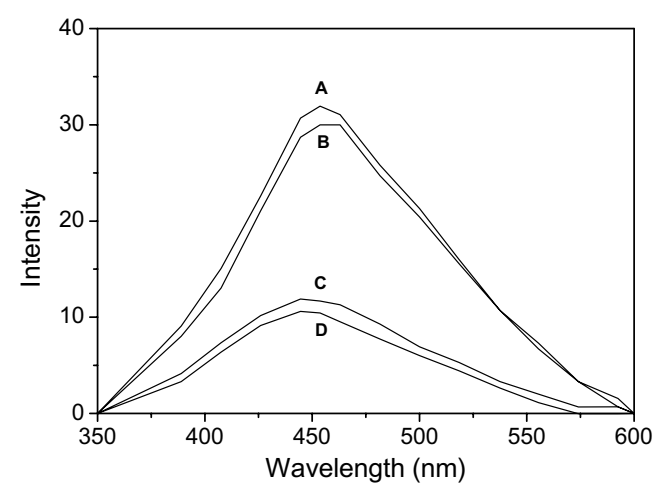

Figure 2. Fluorescence analysis of alginate samples: (a) unpurified SVLV sample; (b) unpurified SVHV sample; (c) purified SVHV sample; (d) purified SVLV sample. was reduced by $52.7 \%$ for both SVLV and SVHV samples. These results are consistent with the values reported by Orive et al. ${ }^{20}$ for Laminaria hyperborea alginates $(63 \%)$. Klöck et al. ${ }^{30}$ reported that the remaining contaminants detected in the fluorescence spectra of alginates from Durviella potatorum (another brown algae) could not be identified. However, in vitro and in vivo biocompatibility tests have shown that these impurities did not induce the production of anti-alginate antibodies. ${ }^{32}$

\section{3. ${ }^{1} \mathrm{H}$ NMR characterization}

Figure 3 shows the ${ }^{1} \mathrm{H}$ NMR spectra for the SVLV and SVHV alginates. Both spectra show the characteristics of the guluronic acid anomeric proton (G-1) at $5.06 \mathrm{ppm}$ (peak I); guluronic acid H-5 (G-5) at $4.4 \mathrm{ppm}$ (peak III); and mannuronic acid anomeric proton (M-1) and the C-5 of alternating blocks (GM-5) overlapped at $4.7 \mathrm{ppm}$ (peak II). ${ }^{1} \mathrm{H}$ NMR spectroscopy is a reliable method for the determination of the composition and also the block structures of alginate molecules. $^{8,9}$ The block structure and $\mathrm{M} / \mathrm{G}$ ratio were calculated using the method proposed by Grasdalen ${ }^{5}$ and Grasdalen et al. ${ }^{6}$ The individual guluronic acid $\left(\mathrm{F}_{\mathrm{G}}\right)$ and the doublet $\left(\mathrm{F}_{\mathrm{GG}}\right)$ fractions can be calculated from the area under the peak (I to III) using the equations

$$
\begin{aligned}
& F_{G}=A_{I} /\left(A_{I I}+A_{I I I}\right) \\
& F_{G G}=A_{I I I} /\left(A_{I I}+A_{I I I}\right)
\end{aligned}
$$

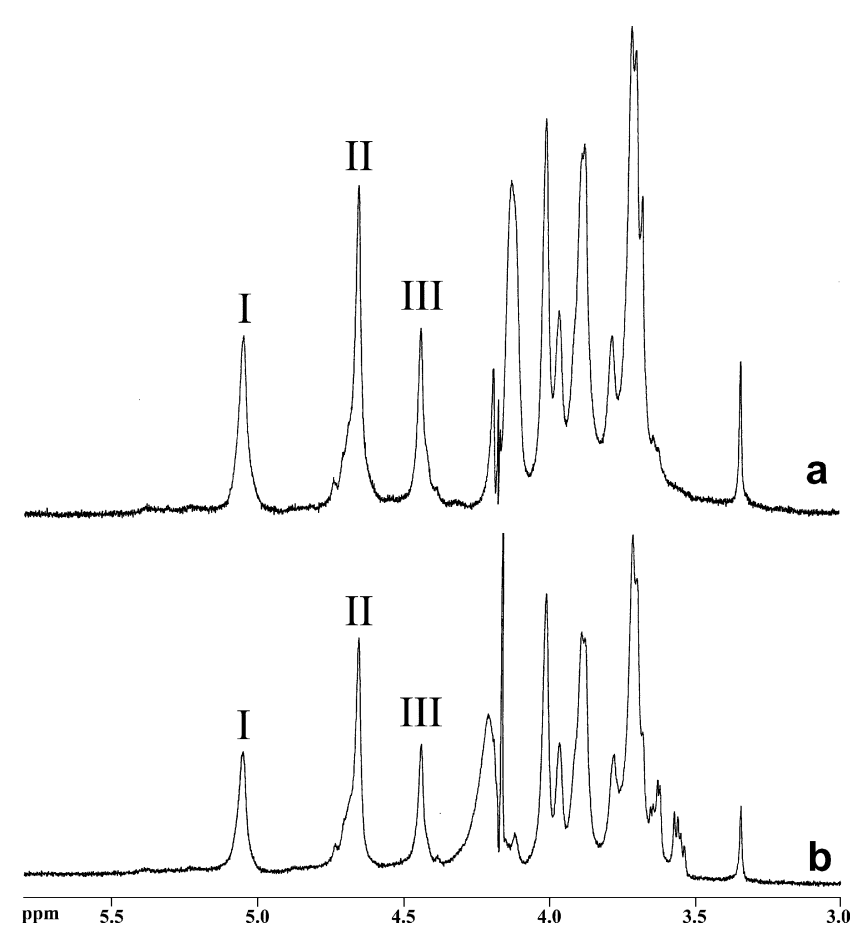

Figure 3. ${ }^{1} \mathrm{H}$ NMR spectra for solution of alginate from $S$. vulgare in $\mathrm{D}_{2} \mathrm{O}$. (a) SVLV; (b) SVHV. 
The fraction $\mathrm{M}$ can be determined by

$$
\mathrm{F}_{\mathrm{M}}=1-\mathrm{F}_{\mathrm{G}}
$$

and the $\mathrm{M} / \mathrm{G}$ ratio is given by

$$
\mathrm{M} / \mathrm{G}=\left(1-\mathrm{F}_{\mathrm{G}}\right) / \mathrm{F}_{\mathrm{G}}
$$

The ability to form gels from alginate is markedly influenced by the uronic acid composition (mannuronic and guluronic acid ratio). ${ }^{33}$ Brittle gels are obtained from alginate with a low $\mathrm{M} / \mathrm{G}$ ratio, while elastic gels are formed from alginate with a high $\mathrm{M} / \mathrm{G}$ ratio. ${ }^{33}$ The comparison of the $\mathrm{M} / \mathrm{G}$ ratio and other data for S. vulgare alginate (SVLV and SVHV) with similar data for alginates from other Sargassum species are given in Table 2. An unusually high $\mathrm{M} / \mathrm{G}$ ratio was observed for $S$. vulgare alginate. The $\mathrm{M} / \mathrm{G}$ ratio values for SVLV and SVHV were 1.56 and 1.27 , respectively, higher than the ratio for most of Sargassum spp. alginates. The M/G ratio varies according to the extraction methodology and location from which the algae were collected. Davis et al. ${ }^{11}$ analyzed the effect of extraction procedures on $\mathrm{M} / \mathrm{G}$ ratio for $S$. fluitans and $S$. oligocystum. The variation in the M/G ratio was $0.52-0.57$ for $S$. fluitans and 0.49-0.62 for S. oligocystum, depending on the extraction procedures. It can be noted that the sample of $S$. fluitans investigated by Davis et al. ${ }^{11}$ had a very low $\mathrm{M} / \mathrm{G}$ ratio when compared with that obtained for the same algae by Forest and Volesky (1.18). ${ }^{7}$ This dissimilarity may be due to the difference in the geographical location of the algae. The results obtained for SVLV are similar to those observed for $S$. fluitans collected from the Gulf of Mexico along the Florida coast. ${ }^{7}$ Higher values for the $\mathrm{M} / \mathrm{G}$ ratio were observed for Laminaria trabeculata seaweed from Chapaco, Chile (1.73), ${ }^{34}$ Ascophyllum nodosum (1.14-1.29), ${ }^{33}$ Macrocystis pyrifera (1.38), ${ }^{33}$ and Laminaria digitata (1.56). ${ }^{35}$

It is not only the $\mathrm{M} / \mathrm{G}$ ratio which has an influence on alginate gelling properties, but also the presence of homopolymeric block structures, that is, mannuronic acid blocks $\left(\mathrm{F}_{\mathrm{MM}}\right)$, guluronic blocks $\left(\mathrm{F}_{\mathrm{GG}}\right)$, and alternating blocks $\left(\mathrm{F}_{\mathrm{MG}}\right)$.

The increasing interest in alginate for industrial application is due to its ability to form gel in the presence of calcium ions. However, the gel formation occurs mainly as a function of the formation of enriched GG junction zones. ${ }^{9}$ Alginate has been used as a bioadsorbent for heavy metals, such as $\mathrm{Cd}^{2+}$, a process which is dependent on the abundance of GG block diads..$^{10,11}$

The doublet fractions $\left(\mathrm{F}_{\mathrm{GG}}\right.$ and $\left.\mathrm{F}_{\mathrm{MM}}\right)$ are obtained from the following relationships: ${ }^{9}$

$$
\begin{aligned}
& \mathrm{F}_{\mathrm{GG}}+\mathrm{F}_{\mathrm{GM}}=\mathrm{F}_{\mathrm{G}} \\
& \mathrm{F}_{\mathrm{MM}}+\mathrm{F}_{\mathrm{MG}}=\mathrm{F}_{\mathrm{M}}
\end{aligned}
$$

Data for doublet fractions of $S$. vulgare are also shown in Table 2. Sargassum alginates possess a high quantity of homopolymeric guluronic blocks $\left(\mathrm{F}_{\mathrm{GG}}\right)$. The alternating block fractions $\left(\mathrm{F}_{\mathrm{MG}}\right.$ and $\left.\mathrm{F}_{\mathrm{GM}}\right)$ range from 0.04 to $0.20 .^{9-11}$ An unusual fraction pattern was obtained in this study for $S$. vulgare alginate. Both samples showed high values for homopolymeric mannuronic acid blocks and lower values for alternating blocks than those previously described in the literature for Sargassum alginates. ${ }^{9-11}$ Low alternating block values have been previously observed for alginate from $S$. latifolium $(0.04),{ }^{9}$ Sargassum thunbergii $(0.05)$ and $S$. polycystum (0.05). ${ }^{11}$ However, these samples are rich in $\mathrm{F}_{\mathrm{GG}}$ blocks. A high $\mathrm{F}_{\mathrm{MM}}$ fraction has been found for alginate from S. fluitans from Florida ${ }^{7}$ and L. digitata, but in these cases the alternating block fraction was much higher (0.17 and 0.24 for S. fluitans and L. digitata, respectively) than the value found for $S$. vulgare samples (0.01-0.03). Different properties of $S$. vulgare alginates are expected.

\subsection{Intrinsic viscosity}

\begin{tabular}{|c|c|c|c|c|c|c|c|c|c|}
\hline Sargassum species & Origin & $F_{M}$ & $\mathrm{~F}_{\mathrm{G}}$ & $\mathrm{M} / \mathrm{G}$ ratio & $\mathrm{F}_{\mathrm{MM}}$ & $\mathrm{F}_{\mathrm{MG}}$ & $\mathrm{F}_{\mathrm{GM}}$ & $\mathrm{F}_{\mathrm{GG}}$ & Ref. \\
\hline S. fluitans & Cuba & 0.34 & 0.66 & 0.52 & 0.25 & 0.09 & 0.09 & 0.57 & 10 \\
\hline S. oligocystum & Australia & 0.38 & 0.62 & 0.62 & 0.31 & 0.07 & 0.07 & 0.55 & 10 \\
\hline S. filipendula & $-^{\mathrm{a}}$ & 0.16 & 0.84 & 0.19 & 0.07 & 0.08 & 0.08 & 0.76 & 11 \\
\hline S. muticum & England & 0.24 & 0.76 & 0.31 & 0.07 & 0.17 & 0.17 & 0.59 & 11 \\
\hline S. polycystum & $\underline{\mathrm{a}}^{\mathrm{a}}$ & 0.18 & 0.82 & 0.21 & 0.12 & 0.05 & 0.05 & 0.77 & 11 \\
\hline S. thunbergii & Korea & 0.34 & 0.66 & 0.53 & 0.17 & 0.17 & 0.17 & 0.48 & 11 \\
\hline S. dentifolium & Egypt & 0.34 & 0.66 & 0.52 & 0.23 & 0.11 & 0.11 & 0.55 & 9 \\
\hline S. asperifolium & Egypt & 0.41 & 0.59 & 0.69 & 0.30 & 0.11 & 0.11 & 0.48 & 9 \\
\hline S. latifolium & Egypt & 0.45 & 0.55 & 0.82 & 0.41 & 0.04 & 0.04 & 0.51 & 9 \\
\hline S. fluitans & Florida & 0.54 & 0.46 & 1.18 & 0.36 & 0.18 & 0.18 & 0.28 & 7 \\
\hline \multicolumn{10}{|l|}{ S. vulgare } \\
\hline HV & Brazil & 0.56 & 0.44 & 1.27 & 0.55 & 0.01 & 0.01 & 0.43 & This study \\
\hline LV & & 0.61 & 0.39 & 1.56 & 0.58 & 0.03 & 0.03 & 0.36 & \\
\hline
\end{tabular}

Intrinsic viscosity is a measure of the hydrodynamic volume occupied by the macromolecule at infinite dilution

Table 2. Compositional data of alginates extracted from species of Sargassum

\footnotetext{
${ }^{\mathrm{a}}$ Unknown origin.
} 
in a specific solvent at a given temperature. It is dependent on the molar mass, composition, and sequence of $M$ and $G$ residues, as well as the ionic strength. Intrinsic viscosity is defined by the Huggins equation as

$$
[\eta]=\lim _{c \rightarrow 0} \eta_{\mathrm{sp}} / c
$$

Intrinsic viscosity was determined in dilute solutions using Eq. 8, where $\eta_{\mathrm{sp}}$ and $\eta_{\mathrm{sp}} / c$ are the specific and reduced viscosity, respectively, and $k_{\mathrm{H}}$ is the Huggins constant

$$
\eta_{\mathrm{sp}} / c=[\eta]+k_{\mathrm{H}}[\eta]^{2} c
$$

The plot of reduced viscosity versus alginate concentration is shown in Figure 4 for SVLV and SVHV samples. The intrinsic viscosities in $0.1 \mathrm{M} \mathrm{NaCl}$ at $25^{\circ} \mathrm{C}$ for SVHV and SVLV were 6.9 and $4.1 \mathrm{dL} / \mathrm{g}$, respectively. These alginates, particularly the SVLV, had low $[\eta]$ values when compared to other Sargassum alginates, which are in the range of $6.3-15.2 \mathrm{dL} / \mathrm{g}$ (Table 3 ). The lower

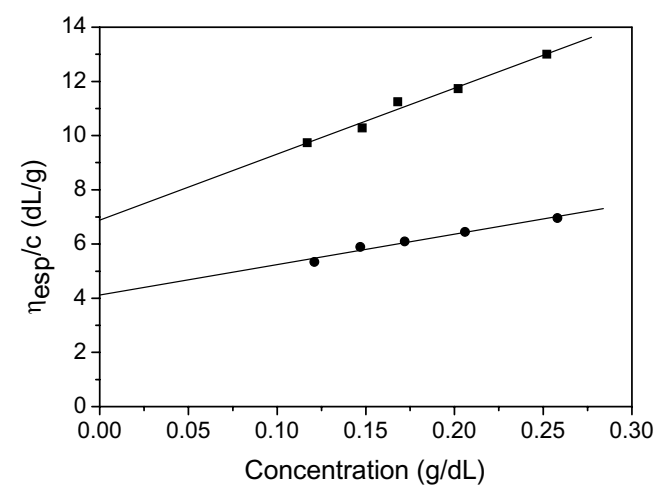

Figure 4. Specific viscosity of SVLV $0.1 \mathrm{M} \mathrm{NaCl}$.

Table 3. Intrinsic viscosity and average molar masses of alginates from different sources

\begin{tabular}{lrll}
\hline Alginate source & {$[\eta](\mathrm{dL} / \mathrm{g})$} & $M_{\mathrm{W}}{ }^{\mathrm{a}} \times 10^{-5}(\mathrm{~g} / \mathrm{mol})$ & Ref. \\
\hline \multicolumn{2}{l}{ Macrocystis pyrifera } & & \\
$\mathrm{HV}$ & 12.1 & 5.83 & 38 \\
MV & 9.6 & 4.60 & 38 \\
LV & 6.2 & 2.95 & 38 \\
L. hyperborea & 6.4 & 3.05 & 38 \\
F. vesiculosus & 2.5 & 1.17 & 7 \\
A. nodosum & 2.8 & 1.32 & 7 \\
L. japonica & 15.4 & 7.44 & 7 \\
S. fluitans & 6.3 & 3.00 & 7 \\
S. dentifolium & 12.6 & 6.06 & 9 \\
S. asperifolium & 15.2 & 7.34 & 9 \\
S. latifolium & 8.7 & 4.16 & 9 \\
S. vulgare & & & \\
$\quad$ LV & 4.1 & 1.94 & This study \\
HV & 6.9 & 3.30 & \\
\hline
\end{tabular}

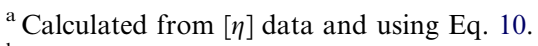

${ }^{\mathrm{b}}$ From Florida. value obtained for SVLV may be due to the high content of $F_{M M}$ fraction in this sample, which is more flexible than the $\mathrm{F}_{\mathrm{GG}}$ fraction. If the $[\eta]$ values of alginate from other algae sources are included in the range (see Table $3)$, the intrinsic viscosity of $S$. vulgare alginates is in the observed range (2.5-15.4).

Due to the low viscosity and high $\mathrm{F}_{\mathrm{MM}}$ fraction the $S$. vulgare alginate samples may not possess the gelling properties required for some alginate applications. However, these characteristics may be useful for obtaining of polyelectrolyte complexes for the production of drug delivery micro- and nanoparticles. In some cases, a charged polysaccharide with low viscosity is needed.

\subsection{Molar mass}

The viscosity average molar mass $\left(M_{\mathrm{v}}\right)$ was determined using the Mark-Houwink equation

$$
[\eta]=k M_{\mathrm{v}}^{a}
$$

where $k$ and $a$ are empirical coefficients dependent on the polymer and solvent-temperature systems. For alginate, $a$ values from 0.73 to 1.31 can be obtained depending on the ionic strength and alginate composition. ${ }^{36,37}$ Higher $a$ values are typical of G-rich alginate, while lower values are observed for M-rich alginates, which are more flexible. ${ }^{4,36}$

On considering alginate from five sources, Clementi et al. $^{38}$ proposed empirical relations for $[\eta]$ and the weight-average molar mass $\left(M_{\mathrm{w}}\right)$

$$
[\eta]=0.023 M_{\mathrm{w}}^{0.984}
$$

where $[\eta]$ is given in $\mathrm{dL} / \mathrm{g}$ and $M$ in kDaltons.

The $M_{\mathrm{w}}$ values for alginates from $S$. vulgare and from other algal sources were estimated from the intrinsic viscosity data, using Eq. 10, as shown in Table 3. The values for all alginates lay within the order of magnitude of $10^{5} \mathrm{~g} / \mathrm{mol}$, including the SVLV and SVHV samples. The molar mass value for SVLV was lower than most values reported for alginates from the Sargassum species, but higher than those obtained for alginates extracted from A. nodosum and Fucus vesiculosus. ${ }^{7}$ SVHV had a molar mass value similar to that reported for S. fluitans, ${ }^{7}$ but lower than those calculated for $S$. dentifolium and $S$. asperifolium. ${ }^{9}$

\subsection{Rheological measurements}

Rheological behavior is an important parameter for the application of polysaccharides in the food industry. Flow curves for Na-purified SVHV and SVLV samples in aqueous solutions were performed in the concentration range of $0.1-1.0 \mathrm{~g} / \mathrm{dL}$ in $0.1 \mathrm{M} \mathrm{NaCl}$ (Fig. 5). In the Power-Law model, the solution behavior can be described by Eq. 11 

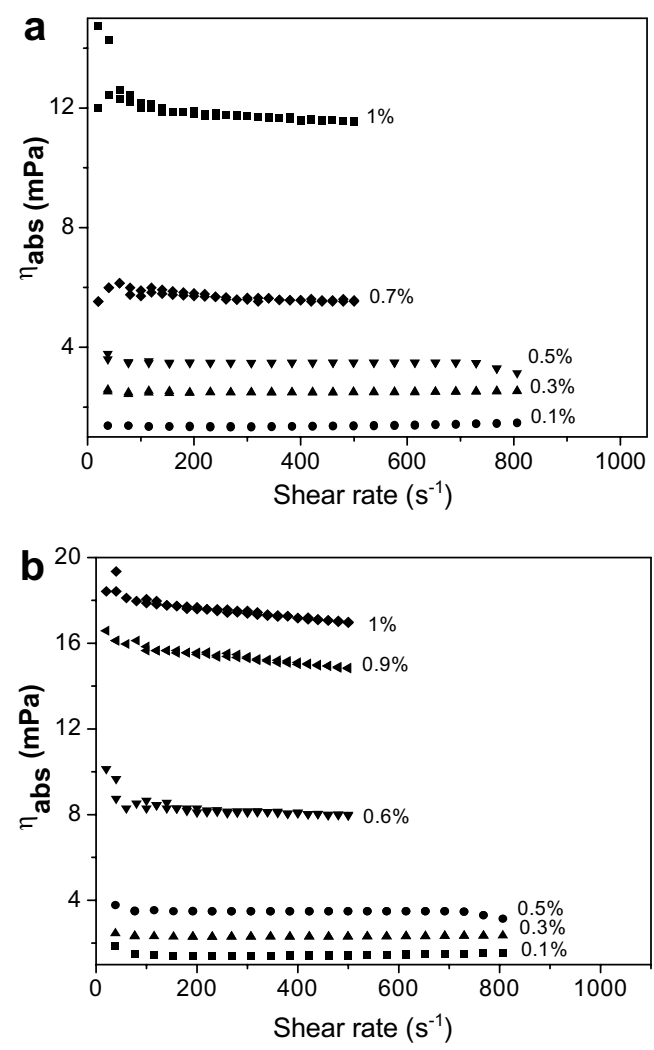

Figure 5. Effect of shear rate on the viscosity of $S$. vulgare alginate solutions in $0.1 \mathrm{M} \mathrm{NaCl}$ at $25^{\circ} \mathrm{C}$. (a) SVHV; (b) SVLV.

$$
\tau=m \gamma^{n}
$$

where $m$ is the consistency index $\left(\mathrm{Pa} \mathrm{s}^{n}\right), n$ is the flow behavior index, $\tau$ is the shear stress and $\gamma$ is the shear rate. The parameters $m$ and $n$ can be obtained by linear regression analysis. ${ }^{39}$ The parameters obtained (Table 4) and the flow behavior index are closer to 1 for Newtonian fluids.

Newtonian behavior is observed for a solution fraction as high as $0.7 \%$ for SVLV, while for the SVHV sample the solutions behaved as Newtonian fluid up to $0.5 \%$. These results differ from those obtained by Mancini et al. ${ }^{40}$ for alginate from $M$. pyrifera $\left(M_{\mathrm{w}}\right.$ as calculated from $[\eta]$ using Eq. 10 range: $2.95 \times 10^{5}$ to $\left.5.83 \times 10^{4} \mathrm{~g} / \mathrm{mol}\right)$ and L. hyperborea $\left(M_{\mathrm{w}}\right.$ as calculated

Table 4. Power-law parameter in $0.1 \mathrm{M} \mathrm{NaCl}$ solutions at different alginate concentration

\begin{tabular}{llllllll}
\hline \multirow{2}{*}{$\begin{array}{l}\text { Concentration } \\
\%(\mathrm{w} / \mathrm{v}))\end{array}$} & \multicolumn{3}{c}{ SVLV sample } & & \multicolumn{3}{c}{ SVHV sample } \\
\cline { 2 - 4 } \cline { 7 - 8 } \cline { 6 - 8 }$\left(\mathrm{Pa} \mathrm{s}^{n}\right)$ & $n^{\mathrm{a}}$ & $R^{\mathrm{b}}$ & & $m\left(\mathrm{~Pa} \mathrm{~s}^{n}\right)$ & $n^{\mathrm{a}}$ & $R^{\mathrm{b}}$ \\
\hline 0.1 & 1.00 & 0.10 & 99.6 & & 1.00 & 0.09 & 98.7 \\
0.3 & 0.96 & 0.22 & 98.9 & & 0.98 & 0.18 & 99.3 \\
0.5 & 0.95 & 0.35 & 98.9 & & 0.97 & 0.26 & 99.2 \\
0.7 & 0.91 & 0.85 & 99.1 & & 0.92 & 0.69 & 99.0 \\
1.0 & 0.91 & 1.00 & 99.1 & & 0.92 & 1.20 & 98.4 \\
\hline
\end{tabular}

\footnotetext{
${ }^{a}$ Dimensionless.
}

${ }^{\mathrm{b}}$ Coefficient of determination. from $[\eta]$ using Eq. $\left.10=3.05 \times 10^{4} \mathrm{~g} / \mathrm{mol}\right)$, where pseudoplasticity was observed for a very low solution concentration of $0.125 \%$.

\section{Acknowledgements}

We are grateful to CENAUREMN-UFC for the NMR spectra and to Conselho de Desenvolvimento Científico e Tecnológico (CNPq-Brazil) for financial support.

\section{References}

1. Sharma, A.; Gupta, M. N. Carbohydr. Polym. 2002, 48, 391-395.

2. Donati, I.; Vetere, A.; Gamini, A.; Skajak-Bræk, G.; Coslovi, A.; Campa, C.; Paoletti, S. Biomacromolecules 2003, 4, 624-631.

3. Llanes, F.; Sauriol, F.; Morin, F. G.; Perlin, A. S. Can. J. Chem. 1997, 75, 585-590.

4. Moe, S. T.; Draget, K. I.; Skajak-Bræk, G.; Smidsrød, O. In Food Polysaccharides and their Applications; Stephen, A., Ed.; Marcel Dekker: New York, 1995; pp 245-286.

5. Grasdalen, H. Carbohydr. Res. 1983, 118, 255-260.

6. Grasdalen, H.; Larsen, B.; Smidsrød, O. Carbohydr. Res. 1979, 68, 23-31.

7. Fourest, E.; Volesky, B. Appl. Biochem. Biotechnol. 1997, 67, 33-44.

8. Panikkar, R.; Brasch, D. J. Carbohydr. Res. 1996, 293, 119-132.

9. Larsen, B.; Salem, D. M. S. A.; Sallan, M. A. E.; Mishrikey, M. M.; Beltagy, A. I. Carbohydr. Res. 2003, 338, 2325-2336.

10. Davis, T. A.; Ramirez, M.; Mucci, A.; Larsen, B. J. Appl. Phycol. 2004, 16, 275-284.

11. Davis, T. A.; Llanes, F.; Volesky, B.; Mucci, A. Environ. Sci. Technol. 2003, 37, 261-267.

12. Holan, Z. R.; Volesky, B.; Prosetyo, I. Biotechnol. Bioeng. 1993, 41, 819-825.

13. Volesky, B.; Kuyucak. N. U.S. Patent 4,769, 223, 1998.

14. Davis, T. A.; Volesky, B.; Vieira, R. H. S. F. Water Res. 2000, 34, 4270-4278.

15. Figueira, M. M.; Volesky, B. Biotechnol. Bioeng. 1997, 54, 334-350.

16. Holan, Z. R.; Volesky, B. Biotechnol. Bioeng. 1994, 43, 1001-1009.

17. Donati, I.; Holtan, S.; Mørch, Y. A.; Borgogna, M.; Dentini, M.; Skajak-Bræk, G. Biomacromolecules 2005, 6, 1031-1040.

18. Mao, W. J.; Li, B. F.; Gu, Q. Q.; Fang, Y. C.; Xing, H. T. Hydrobiologia 2004, 512, 263-266.

19. Raghvendran, H. R. B.; Sathivel, A.; Devaki, T. Mol. Cell. Biochem. 2005, 276, 89-96.

20. Orive, G.; Ponce, S.; Hernández, M. R.; Gascón, R. A.; Igartua, M.; Pedraz, L. J. Biomaterials 2002, 23, 38253831.

21. Chen, H.; Ouyang, W.; Jones, M.; Hague, T.; Lawuyi, B.; Prakash, S. J. Microencapsulation 2005, 22, 539-547.

22. Kim, M. S.; Park, G. D.; Jun, S. W.; Lee, S.; Park, J. S.; Hwang, S. J. J. Pharm. Pharmacol. 2005, 57, 15211528. 
23. Pereira, L.; Sousa, A.; Coelho, H.; Amado, M. A.; Ribeiro-Claro, A. J. P. Biomol. Eng. 2003, 20, 223-228.

24. Barbarino, E.; Lourenço, S. O. J. Appl. Phycol. 2005, 17, 447-460.

25. Ramos, M. V.; Monteiro, A. C. O.; Moreira, R. A.; Carvalho, A. D. F. U. J. Food Biochem. 2000, 24, 3339.

26. Marinho-Soriano, E.; Fonseca, P. C.; Carneiro, M. A. A.; Moreira, W. S. C. Bioresour. Technol. 2006, 97, 24022406.

27. Romanos, M. T. V.; Andrade-Serpa, M. J.; dos Santos, M. G. M.; Ribeiro, A. C. F.; Yoneshigue-Valentin, Y.; Costa, S. S.; Wigg, M. D. Cancer Invest. 2002, 20, 46-54.

28. Dietrich, C. P.; Farias, G. G. M.; de Abreu, L. R. D.; Leite, E. L.; da Silva, L. F.; Nader, H. B. Plant Sci. 1995, 108, 143-153.

29. Calumpong, P. H.; Maypa, P. A.; Magbanua, M. Hydrobiologia 1999, 398, 211-215.

30. Klöck, G.; Frank, H.; Houben, R.; Zekorn, T.; Horcher, A.; Siebers, U.; Wöhrle, M.; Federlin, K.; Zimmermann, U. Appl. Microbiol. Biotechnol. 1994, 40, 638-643.
31. Dusseault, J.; Tam, S. K.; Menard, M.; Polizu, S.; Jourdan, G.; Yahia, L.; Halle, J. P. J. Biomed. Mater. Res. Part A 2006, 76 A, 243-251.

32. Klöck, G.; Pfeffermann, A.; Ryser, C.; Grohn, P.; Kuttler, B.; Hahn, H.-J.; Zimmermann, U. Biomaterials 1997, 18, 707-713.

33. Penman, A.; Sanderson, G. R. Carbohydr. Res. 1972, 25, 273-282.

34. Chandria, N. P.; Matsuhiro, B.; Vasquez, A. E. Carbohydr. Polym. 2001, 46, 81-87.

35. Grasdalen, H.; Larsen, B.; Smidsrød, O. Carbohydr. Res. 1972, 56, C11-C15.

36. Mackie, W.; Noy, R.; Sellen, D. B. Biopolymers 1980, 19 , 1839-1860.

37. Martinsen, A.; Skjak-Bræk, G.; Smidsrød, O. Carbohydr. Polym. 1991, 15, 171-193.

38. Clementi, F.; Mancini, M.; Moresi, M. J. Food Eng. 1998, $36,51-62$.

39. Marcotte, M.; Hoshahili, R. A. T.; Ramaswamy, S. H. Food Res. Int. 2001, 34, 695-703.

40. Mancini, M.; Moresi, M.; Sappino, F. J. Food Eng. 1996, $28,283-295$. 